\title{
Phytochemical, pharmacological and GC-MS characterization of the lipophilic fraction of Monotheca buxifolia
}

\author{
Shabnam Javed ${ }^{1}$, Amna Shoaib ${ }^{2}$, Zaid Mahmood ${ }^{3}$, Shaista Nawaz ${ }^{4}$, Khalid Mohammed Khan ${ }^{5}$ \\ ${ }^{1}$ Institute of Chemistry, University of the Punjab, Quaid-e-Azam Campus, Lahore, Pakistan \\ ${ }^{2}$ Institute of Agricultural Sciences, University of the Punjab, Lahore, Pakistan \\ ${ }^{3}$ Department of Chemistry, The University of Lahore, Pakistan \\ ${ }^{4}$ Food and Biotechnology Research Centre (FBRC), Pakistan Council of Scientific \& Industrial Research Laboratories \\ Complex, Lahore, Pakistan \\ ${ }^{5}$ H. E. J. Research Institute of Chemistry, International Center for Chemical and Biological Sciences, University of Karachi, \\ Karachi, Pakistan
}

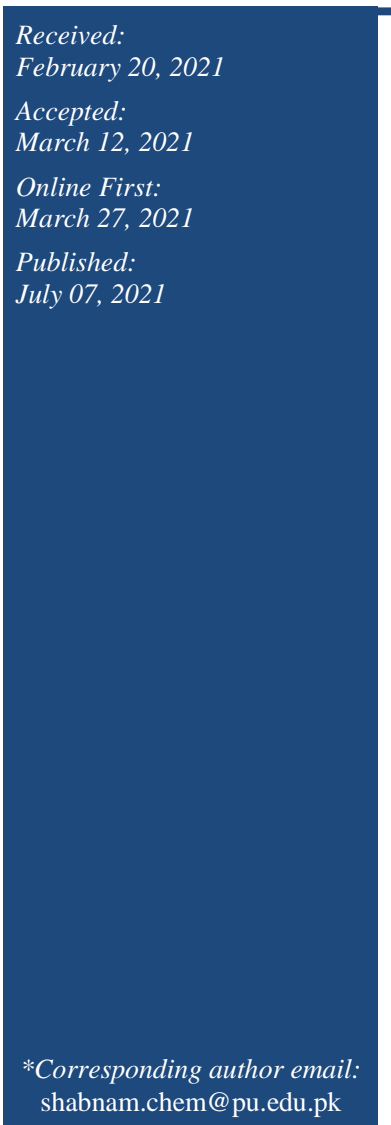

\begin{abstract}
Monotheca buxifolia [(Falc.) A. DC.] indigenous to northern Pakistan is a broad-leaved evergreen traditional plant of pharmacological versatility. The present investigation focused on evaluating the phytochemistry, nutritional profile, analgesic activity, cytotoxicity and GC-MS profile of $M$. buxifolia. The result showed aerial parts of $M$. buxifolia had high content of carbohydrate and protein, along with sufficient amounts of macro and micronutrients. The lipophilic $n$-hexane fraction of M. buxifolia exhibited the presence of saponins (29.30\%), flavonoids (18\%) and phenols (0.46 mg GAE/100 g). Analgesic activity of lipophilic fraction was equivalent to standard drug (Aspirin) as determined by the tail flick method. The F1 (oily liquid) of lipophilic fraction showed significant cytotoxicity against lung adenocarcinoma (A549) and liver (HepG2) cell lines). GC-MS profiling identified cis-vaccenic acid followed by $n$ hexadecanoic acid and hexadecanoic acid, methyl ester as major bioactive compounds in the lipophilic oily sub-fraction of $M$. buxifolia. These results support the use of oily sub-fraction of $M$. buxifolia as an effective and safe candidate for treatment of cancer cell lines.
\end{abstract}

Keywords: Gurgura, Macro micronutrient, Phytoconstitutents, Tail-flicking method, MTT assay

\section{How to cite this:}

Javed S, Shoaib A, Mahmood Z, Nawaz S and Khan KM, 2021. Phytochemical, pharmacological and GC-MS characterization of the lipophilic fraction of Monotheca buxifolia. Asian J. Agric. Biol. 2021(3): 202102073. DOI: https://doi.org/10.35495/ajab.2021.02.073

This is an Open Access article distributed under the terms of the Creative Commons Attribution 3.0 License. (https://creativecommons.org/licenses/by/3.0), which permits unrestricted use, distribution, and reproduction in any medium, provided the original work is properly cited.

\section{Introduction}

Monotheca buxifolia (Falc.) A. DC. is an economically and medically important plant, native to Pakistan, distributed in North-West regions of the country. It is used as folk medicine in different treatments such as a hematinic, laxative, digestive, anthelmintic, antipyretic, and urinary disorders, In Pakistan, local herbal medicine practitioners utilized its various parts against stomach ailments, cystitis, 
headache, toothache, diabetes, cough, jaundice, and dermatitis (Ullah et al., 2016). M. buxifolia has been investigated for hepatoprotective, anticancerous, antinociceptive, antipyretic, anti-inflammatory, cytotoxicity and urease enzyme inhibitory potentials due to high level of high antioxidant activity and diverse classes of flavonoids, phenolics and terpenoids derivatives (Burki et al., 2019; Ali et al., 2020).

Generally, phytochemicals exhibit fairly low bioavailability as they are handled by the body as xenobiotics therefore the presence in the body is ephemeral. Therefore, bioavailability of dietary phytochemicals to target cells facilitate their bioefficacy to protect our health (D'Archivio et al., 2010). Chemical structures and dietary intake forms are among the key features affecting the bioavailability of phytochemicals (Selby-Pham et al., 2017). Lipophilic drugs or "fat friendly" are among the non-ionized drugs which diffuse easily in the body by penetrating the cell membrane as compared to delayed drug permeation by ionized hydrophilic drugs ( $\mathrm{Gu}$ et al., 2007). Lipophilicity property of the phytochemical is also considered as the most significant in influencing ligand-target binding interactions, solubility, ADME (absorption, distribution, metabolism, and elimination) properties, as well as in vivo toxicological outcomes, and, therefore, the overall quality of the drug candidate. Antioxidant, functional, nutritional and structural contributions of many lipophilic phytochemicals (e.g. sterols, carotenoids and tocols) have been known in the human body (Raikos and Ranawana, 2017). Lipophilic phytochemicals have been reported to reduce cardiovascular associated risk by lowering plasma cholesterol (Dinu et al., 2018). Due to pharmacological versatility of $M$. buxifolia, the current study was performed to analyze phytochemical profile of lipophilic fraction of $M$. buxifolia, and to assess its analgesic activity in addition to nutritional assessment of aerial plant parts. Besides, oily subfraction of lipophilic fraction was isolated and examined for cytotoxic activity against two human cancer cell lines (lung A549 and liver HepG2), and GC-MS analysis was performed to identify bioactive components of in oily sub-fraction.

\section{Material and Methods}

\section{Proximate and mineral assays of $M$. buxifolia}

The aerial parts (stem, flowers, leaves, and spines) of M. buxifolia (GC. Bot. Herb. 815) were analyzed for moisture content, protein, carbohydrate, fats and ash
(AOAC, 1990). Concentration of heavy metals (Mg and $\mathrm{Fe}$ ) were recorded through an atomic absorption spectrometer, while carbon, hydrogen, nitrogen and sulphur were assessed through a C/S determinator.

\section{Extraction of lipophilic fraction}

Dried aerial plant's parts $(5.6 \mathrm{~kg})$ were crushed by a mechanical grinder into a coarse powder followed by maceration using methanol $(15 \mathrm{~L})$. After 7 days, the solvent was removed under vacuum by rotary evaporator, and the gummy mass was diluted with half liter water further partitioned using $n$-hexane to yield lipophilic fraction $(170 \mathrm{~g})$.

\section{Quantitative and qualitative phytochemical analyses of lipophilic fraction}

Preliminary phytochemical evaluation for the detection of phytochemicals in lipophilic fraction were performed using standard methods (Sofowora, 1993; Harborne, 1998). The amount of phenolic content in the lipophilic fraction was measured by the FolinCiocalteau scheme, while flavonoids were determined by the method of Bohm and Abyazani (1994). Saponins were quantified using methods described by Obadoni and Ochuko (2001).

\section{Analgesic activity of lipophilic fraction}

Lipophilic fraction was evaluated for analgesic activity in albino mice (male)using tail flick model (Williamson et al.,1997) and trial was carried out following the ethical principles for laboratory animal's care (Zimmerman, 1983). Albino mice weighing between $200-250 \mathrm{~g}$ were randomly divided into two groups, with five animals in each group. The animals in group 1 (control) received standard drug, aspirin $(300 \mathrm{mg} / \mathrm{kg}$ ) and group 2 received lipophilic fraction (300 mg/kg). Both groups received treatment by oral route. Pain was induced by placing mice on the analgesiometer with the tail freely protruding out of the holder, and the tail was dipped from the terminal portion radiant heat source. Intensity of the current passing through the naked nichrome wire was 5 ampere. Tail-flick latency was measured at different time intervals till 4.5 hours after the drug administration.

\section{Sub-fractionation of lipophilic fraction and cytotoxic activity assays}

Oily sub fraction (F1: yellow viscous oily mass: $3.2 \mathrm{~g}$ ) obtained through vacuum liquid chromatography and lipophilic sub-fraction were examined for cytotoxicity 
activity against A549 (lung adenocarcinoma) and HepG-2 (hepatocellular carcinoma) cell lines using MTT (3-(4,5-dimethyl-thiazol-2-yl)-2,5diphenyltetrazolium bromide) (Mosmann, 1983). About $1 \mathrm{ml}$ of each cell suspension was added in $2 \times$ 24 well plates after diluting cancer cells $\left(1 \times 10^{3}\right.$ cells $/ \mathrm{mL}$ ). Following the incubation period of 24 hours at $37{ }^{\circ} \mathrm{C}$, the media was first replaced with $1 \mathrm{~mL}$ of lipophilic fraction and sub-fraction, and after another 24 hours, the fractions were replaced with $1 \mathrm{~mL}$ dye reagent. Absorbance of the samples were recorded at $570 \mathrm{~nm}$ through microplate ELISA reader.

\section{GC-MS of the oily sub fraction}

GC-MS analysis of oily sub fraction was performed on gas chromatograph (Shimadzu GC-9A) equipped with capillary column (SPB-5) maintained with flame ionization detector at $220{ }^{\circ} \mathrm{C}$. Carrier gas $\left(\mathrm{N}_{2}: 1.0\right.$ $\mathrm{mL} / \mathrm{min}$ ) was adjusted at initial temperature at $50{ }^{\circ} \mathrm{C}$ for initial $5 \mathrm{~min}$, followed by increase in temperature $\left(5^{\circ} \mathrm{C} / \mathrm{min}\right.$ ) up to $235^{\circ} \mathrm{C}$ and finally sustained for $5 \mathrm{~min}$. A column (HP-5 with dimensions: $25 \mathrm{~m} \times 0.22 \mathrm{~mm}$ and $0.25 \mu \mathrm{mdf}$ ) was used to complete analysis of the fraction.

\section{Results and Discussion}

Nature has bestowed potential in plants to synthesize diversity of chemical compounds of therapeutic properties, while significance of many medicinal plants still need to be explored. M. buxifolia is one of the economically and medically important plants, enriched with many bioactive compounds (Khan et al., 2020). Hence, in the current investigation aerial parts of $M$. buxifolia were initially analyzed for phytochemicals and mineral contents, then lipophilic fraction was assessed for phytochemistry and analgesic activity, and finally sub-fractionation of lipophilic fraction was tested for cytotoxic activity.

\section{Proximate and mineral analysis of aerial parts of M. buxifolia}

Initially phytochemical analysis indicated that aerial parts of M. buxifolia contained $71.80 \%$ carbohydrates, $20.60 \%$ protein, $1.75 \%$ fats, $0.30 \%$ ash and $5.55 \%$ moisture content, respectively (Table 1). Previous findings recorded carbohydrates $(63-74 \%)$, protein (0.85-4.37\%), fats (4.07-7.70\%), ash (6.01-17.67\%) and moisture (10.27-15.50\%) content in medicinal plants including Monotheca buxifolia Geranium wallichianum and Saxifraga flagillaris (Begum et al.,
2018). High content of carbohydrate of $M$. buxifolia could serve as main energy donor, since crude protein and fat contribute only in small portion, while sufficient protein content may be helpful in fulfilling intake of dietary protein $(0.8 \mathrm{~g} / \mathrm{kg}$ of body weight $)$ as prescribed in health guidelines (EFSA, 2012). Fat content may indicate therapeutic advantage in terms of preserving insulin (Nagao and Yanagita, 2010). Macro and micronutrients contribute in the curative property of the plant as these elements participate in structuralfunctional qualities of the plant. Currently, magnesium $(3.10 \mathrm{ppm})$ and iron $(1.60 \mathrm{ppm})$ were detected in reasonable amounts, while carbon, hydrogen, nitrogen and sulphur were present as $46.82 \%, 6.51 \%, 2.32 \%$ and $0.38 \%$, respectively (Table 1 ). Role of magnesium in bone formation, energy metabolism and enzymatic catalysis has been established (Ishimi, 2010), while essentiality of iron in haemoglobin synthesis, oxygen transport and boosting body immunity is known (Soyano and Gomez, 1999). Sree and Vijayalakshmi (2018) also recorded high levels of magnesium and iron in leaves of medicinal plant, Alternanthera sessilis.

Table-1. Proximate and mineral analysis of aerial parts of M. buxifolia

\begin{tabular}{|l|c|}
\hline Nutrients & \% \\
\hline Moisture & 5.55 \\
\hline Ash & 0.30 \\
\hline Fat & 1.75 \\
\hline Protein & 20.60 \\
\hline Carbohydrates & 71.80 \\
\hline Elements & \\
\hline Carbon $(\mathrm{C})$ & 46.82 \\
\hline Hydrogen $(\mathrm{H})$ & 6.51 \\
\hline Nitrogen $(\mathrm{N})$ & 2.31 \\
\hline Sulphur $(\mathrm{S})$ & $0.38 \%$ \\
\hline & $\mathbf{p p m}$ \\
\hline Magnesium $\mathrm{Mg})$ & 3.10 \\
\hline Iron $(\mathrm{Fe})$ & 1.60 \\
\hline
\end{tabular}

\section{Qualitative and qualitative phytochemical determination of lipophilic fraction}

Lipophilic fraction showed presence of saponins, phenols, flavonoids, sterols and terpenoids (Table-2), while qualitative assays revealed $29.30 \%$ saponins, $0.46 \mathrm{mg}$ GAE$/ 100 \mathrm{~g}$ phenols and $8.0 \%$ flavonoids (Table-3). These results may indicate a large number of diverse bioactive compounds in the plant extracts, and the solvent utilized was also suitable to extract 
these bioactive compounds present in M. buxifolia (Ali et al., 2020). Jan et al. (2013) in their findings correlated the antioxidant activity of $M$. buxifolia with the phenolics and flavonoids contents of the fruit. Therefore, phenolic and flavonoid contents may be indication of potent immune-boosting agents due to their unique structural and functional properties. Furthermore, antioxidant, anticancer, and cardioprotective activity of the polyphenolics and flavonoids have been evidenced (Vlaisavljević et al., 2019).

Table-2. Qualitative phytochemical analysis of $M$. buxifolia lipophilic fraction.

\begin{tabular}{|l|c|}
\hline Phytochemicals & $\begin{array}{l}(+)=\text { present, }(-)=\text { absent, }(++)= \\
\mathbf{5 0 \%} \text { or }>\mathbf{5 0} \%\end{array}$ \\
\hline Alkaloids & - \\
\hline Terpenoids & ++ \\
\hline Sterols & ++ \\
\hline Saponins & + \\
\hline Phenols & + \\
\hline Flavonoids & + \\
\hline Tannins & - \\
\hline
\end{tabular}

Table-3. Total phenol, flavonoid and saponin content of M. buxifolia lipophilic fraction.

\begin{tabular}{|l|c|}
\hline Phytochemicals & Total content \\
\hline Phenol & $0.46(\mathrm{mg} \mathrm{GAE} / 100 \mathrm{~g})$ \\
\hline Flavonoid & $18(\%)$ \\
\hline Saponins & $29.3(\%)$ \\
\hline
\end{tabular}

Analgesic activity of $M$. buxifolia lipophilic fraction Analgesic activity of lipophilic fraction of $M$. buxifolia was comparable with the standard drug Aspirin at same dose $(300 \mathrm{mg} / \mathrm{kg})$ at different time intervals (Table-4). In comparison to aspirin (standard drug), the lipophilic fraction exhibited significant analgesic activity in the tail flick method by increasing the latency time of responses. After two hours, the peak activity was observed in either treatment. Moreover, no death or signs of toxicity was observed with lipophilic fraction, which proposes that fraction and its dose were tolerable and safe for the mice. The long duration of analgesic activity of the lipophilic fraction of $M$. buxifolia proposed effectiveness of active metabolite in the fraction and these metabolites could also be accountable for activation of opioid receptors. The tail flick method is generally used to evaluate centrally acting analgesics, which may suggest that the lipophilic fraction activates the opioid receptors in the central nervous system (Hijazi et al., 2017).
Table-4. Analgesic effect of lipophilic fraction of $M$. buxifolia in tail response of mice.

\begin{tabular}{|c|c|c|}
\hline $\begin{array}{l}\text { Reaction Time (hour) } \\
\text { after administration of } \\
\text { sample }\end{array}$ & $\begin{array}{c}\text { Lipophilic } \\
\text { fraction } \\
(\mathbf{3 0 0} \mathbf{~ m g} / \mathbf{k g})\end{array}$ & $\begin{array}{c}\text { Aspirin } \\
(\mathbf{3 0 0} \mathbf{~ m g} / \mathbf{k g})\end{array}$ \\
\hline $0 \mathrm{~h}$ & $2.37^{\mathbf{b}} \pm 0.12$ & $1.01^{\mathbf{d}} \pm 0.23$ \\
\hline $0.5 \mathrm{~h}$ & $2.18^{\mathbf{c}} \pm 0.33$ & $4.80^{\mathbf{a}} \pm 3.13$ \\
\hline $1 \mathrm{~h}$ & $4.23^{\mathbf{a}} \pm 0.51$ & $3.80^{\mathbf{b}} \pm 2.10$ \\
\hline $2.0 \mathrm{~h}$ & $4.85^{\mathbf{a}} \pm 0.13$ & $4.60^{\mathbf{a}} \pm 0.31$ \\
\hline $2.5 \mathrm{~h}$ & $4.75^{\mathbf{a}} \pm 0.14$ & $3.40^{\mathbf{b}} \pm 0.42$ \\
\hline $3 \mathrm{~h}$ & $3.38^{\mathbf{b}} \pm 0.75$ & $3.80^{\mathbf{b}} \pm 0.42$ \\
\hline $3.5 \mathrm{~h}$ & $4.14^{\mathbf{a}} \pm 1.36$ & $2.20^{\mathbf{c}} \pm 2.12$ \\
\hline $4.0 \mathrm{~h}$ & $3.27^{\mathbf{b}} \pm 0.33$ & $2.40^{\mathbf{c}} \pm 0.21$ \\
\hline $4.5 \mathrm{~h}$ & $3.26^{\mathbf{b}} \pm 0.21$ & $2.60^{\mathbf{c}} \pm 0.12$ \\
\hline
\end{tabular}

\pm indicate standard errors of mean of three replicates. Values with different letters show significant difference $(p \leq 0.05)$ as determined by LSD-test.

\section{Cytotoxic effect of lipophilic oily sub-fraction}

The cytotoxic effect of lipophilic fraction and oily subfraction of $M$. buxifolia were evaluated based on effectiveness of fraction that give at least $50 \%$ of the cancer cell survivability $\left(\mathrm{IC}_{50}\right)$ (Table-5). The four categories of extracts have been proposed very active $\left(\mathrm{IC}_{50} \leq 20 \mu \mathrm{g} / \mathrm{mL}\right)$, moderately active $\left(\mathrm{IC}_{50}>20-100\right.$ $\mu \mathrm{g} / \mathrm{mL})$, weakly active $\left(\mathrm{IC}_{50}>100-1000 \mu \mathrm{g} / \mathrm{mL}\right)$ and inactive $\left(\mathrm{IC}_{50}>1000 \mu \mathrm{g} / \mathrm{mL}\right) . \quad \mathrm{IC}_{50}$ for pure compounds or drugs is taken potent, when value $<4$ $\mu \mathrm{g} / \mathrm{mL}$ (Lee and Houghton, 2005). Cytotoxic analysis showed doxorubicin (standard control) exhibited high cytotoxic effect $\left(\mathrm{IC}_{50}\right.$ values $\left.\leq 10.6 \mu \mathrm{g} / \mathrm{mL}\right)$ in both the cell lines. Lipophilic fraction of $M$. buxifolia was moderately active as it depicted $\mathrm{IC}_{50}$ values of 67.40 and $77.20 \mu \mathrm{g} / \mathrm{mL}$ for A549 and HepG2 cancer cell lines, respectively. However, oily sub-fraction of lipophilic fraction was found to be highly active $\left(\mathrm{IC}_{50}\right.$ : 28.20, $15.21 \mu \mathrm{g} / \mathrm{mL}$ for A549 and HepG2, respectively) (Table-5). Javed et al. (2016) has also documented moderate cytotoxicity of $M$. buxifolia hexane fraction $\left(\mathrm{IC}_{50}: 59.20 \mu \mathrm{g} / \mathrm{mL}\right.$ ) against the human lung cancer cell line NCI-H460. Difference in cytotoxic response of cancer cell towards lipophilic fraction and its oily-sub fraction might be due to difference in the bioactive compounds. Hence, oilysub fraction lipophilic fraction obtained by vacuum liquid chromatography, effectively inhibited cancer cell growth. Vacuum liquid chromatography may be advantageous compared with other methods of extracting active components from plant material due 
to low cost and simplicity (Mroczek et al., 2020).

Table-5. Cytotoxic activity ( IC $_{50}$ values) of lipophilic fraction and sub-fraction of M. buxifolia .

\begin{tabular}{|l|c|c|}
\hline \multirow{2}{*}{\multicolumn{1}{c|}{ Treatments }} & \multicolumn{2}{|c|}{ IC $_{\mathbf{5 0}}$ values $(\boldsymbol{\mu g} / \mathbf{m L})$} \\
\cline { 2 - 3 } & $\mathbf{A 5 4 9}$ & HepG2 \\
\hline Lipophilic fraction & $67.40 \pm 3.02$ & $77.2 \pm 2.01$ \\
\hline Lipophilic oily sub-fraction & $28.20 \pm 4.01$ & $15.20 \pm 4.01$ \\
\hline Control (Without Drug) & $>100$ & $>100$ \\
\hline Doxorubicin & $9.70 \pm 1.82$ & $8.50 \pm 3.21$ \\
\hline
\end{tabular}

\pm standard error of the mean three replicates.

Table-6. Pharmacological components identified in the lipophilic oily fraction of M. buxifolia [GC-MS study].

\begin{tabular}{|c|c|l|c|c|c|}
\hline $\mathbf{S .}$ & $\mathbf{R . T}$ & \multicolumn{1}{|c|}{ Name } & M. F & M. W & $\begin{array}{c}\text { Peak } \\
\text { area } \\
(\%)\end{array}$ \\
\hline $\mathbf{1}$ & 17.22 & $\begin{array}{l}\text { Pentanedioic acid, (2,4-di-t- } \\
\text { butylphenyl) mono-ester }\end{array}$ & $\mathrm{C}_{19} \mathrm{H}_{28} \mathrm{O}_{4}$ & 320 & 0.42 \\
\hline $\mathbf{2}$ & 25.07 & Hexadecanoic acid, methyl ester & $\mathrm{C}_{17} \mathrm{H}_{34} \mathrm{O}_{2}$ & 270 & 6.61 \\
\hline $\mathbf{3}$ & 26 & $n$-Hexadecanoic acid & $\mathrm{C}_{16} \mathrm{H}_{32} \mathrm{O}_{2}$ & 256 & 24.84 \\
\hline $\mathbf{4}$ & 26.95 & $\begin{array}{l}9,12-\text { Octadecadienoic acid } \\
\text { (Z,Z)-, methyl ester }\end{array}$ & $\mathrm{C}_{19} \mathrm{H}_{34} \mathrm{O}_{2}$ & 294 & 3.48 \\
\hline $\mathbf{5}$ & 27.03 & $\begin{array}{l}\text { 9-Octadecenoic acid }(\mathrm{Z})-, \\
\text { methyl ester }\end{array}$ & $\mathrm{C}_{19} \mathrm{H}_{36} \mathrm{O}_{2}$ & 296 & 3.07 \\
\hline $\mathbf{6}$ & 27.07 & $\begin{array}{l}\text { 9-Octadecenoic acid, methyl } \\
\text { ester, (E)- }\end{array}$ & $\mathrm{C}_{19} \mathrm{H}_{36} \mathrm{O}_{2}$ & 296 & 3.63 \\
\hline $\mathbf{7}$ & 27.3 & Methyl stearate & $\mathrm{C}_{19} \mathrm{H}_{38} \mathrm{O}_{2}$ & 298 & 2.25 \\
\hline $\mathbf{8}$ & 28.07 & cis-vaccenic acid & $\mathrm{C}_{18} \mathrm{H}_{34} \mathrm{O}_{2}$ & 282 & 40.28 \\
\hline $\mathbf{9}$ & 28.13 & Octadecanoic acid & $\mathrm{C}_{18} \mathrm{H}_{36} \mathrm{O}_{2}$ & 284 & 5.72 \\
\hline $\mathbf{1 0}$ & 47.25 & Lupeol & $\mathrm{C}_{30} \mathrm{H}_{50} \mathrm{O}$ & 426 & 3.34 \\
\hline $\mathbf{1 1}$ & 48.28 & 12-Oleanen-3-yl acetate, $(3 \alpha)-$ & $\mathrm{C}_{32} \mathrm{H}_{52} \mathrm{O}_{2}$ & 468 & 2.46 \\
\hline $\mathbf{1 2}$ & 49.87 & lup-20(29)-en-3-ol,acetate, $(3 \alpha)-$ & $\mathrm{C}_{32} \mathrm{H}_{52} \mathrm{O}_{2}$ & 468 & 3.90 \\
\hline
\end{tabular}

\section{GC-MS analysis of lipophilic oily sub-fraction}

GC-MS analysis of active lipophilic oily sub-fraction indicated occurrence of 12 compounds. (Table-6). Cis-vaccenic acid (8) was identified as most frequently occurring compound followed by $n$-hexadecanoic acid (3) and hexadecanoic acid, methyl ester (2). Cisvaccenic acid (mono-unsaturated fatty acid) is biosynthesized in humans by hepatic fatty acid elongase 5, and. it considerably reduced (23\%) growth of HT-29 human colon cancer cells (Banni et al., 2001). Numerous further studies have confirmed the anti-inflammatory effects of mono-unsaturated fatty acids (Aimola et al., 2016). Aparna et al. (2012) recorded high anti-inflammatory action of $n$ hexadecanoic acid (saturated fatty acid) through reducing production of the inflammatory mediators.
Likewise, hexadecanoic acid methyl esters are reported to have anti-inflammatory, cancer preventive, hepatoprotective, antiarthritic, and anti-coronary properties (Krishnamoorthy and Subramaniam, 2014). Other compounds were classified among less frequently occurring compounds, however, these compounds have been known as important with rest to pharmacology. The linoleic acid esters $(4,5)$ act as antitumour, anti-arthritic agent and anti-inflammatory mediator. Lupeol, lup-20(29)-en-3-ol, acetate, $(3 \alpha)$ and 12-Oleanen-3-yl- acetate, $(3 \alpha)(10-12)$ have been stated for cytotoxic, antitumor, antiflu, antimalarial, antiviral activities and anti-inflammatory potential (Maragreth et al., 2009).

\section{Conclusion}

In conclusion, the contemporary study specifies that aerial parts of $M$. buxifolia contained high content of carbohydrate and protein, and sufficient amount of macro and micronutrients. Lipophilic fraction contained saponins, phenols, flavonoids, sterols and terpenoids, while qualitative assays revealed substantial quantity of saponin, phenolics and flavonoids. Analgesic activity of lipophilic fraction was comparable to aspirin. The cytotoxic effect of lipophilic oily sub-fraction was better than lipophilic fraction against cancer cells. GC-MS profiling identified cis-vaccenic acid followed by $n$ hexadecanoic acid and hexadecanoic acid, methyl ester as major compound bioactive compounds in the lipophilic oily sub-fraction of $M$. buxifolia. These results support the use of oily sub-fraction of $M$. buxifolia as effective and safe candidate for treatment of cancer cell lines.

\section{Acknowledgement}

Authors are grateful for University of the Punjab, Lahore, Pakistan to fund this work.

Disclaimer: None.

Conflict of Interest: None.

Source of Funding: This study was funded by University of the Punjab, Lahore, Pakistan.

\section{References}

AOAC (Association of Official Analytical Chemists), 1990. Official methods of analysis. $15^{\text {th }}$ edition. 
Washington DC, USA.

Aimola IA, Inuwa HM, Nok AJ, Mamman AI and Bieker JJ, 2016. Cis-vaccenic acid induces differentiation and up-regulates Gamma globin synthesis in K562, JK1 and transgenic mice erythroid progenitor Stem Cells. Eur. J. Pharmacol. 776: 9-18.

Ali JS, Saleem H, Mannan A, Zengin G, Mahomoodally MF, Locatelli M and Zia M, 2020. Metabolic fingerprinting, antioxidant characterization, and enzyme-inhibitory response of Monotheca buxifolia (Falc.) A. DC. extracts. Complement. Med. Ther. 20: 313.

Aparna V, Dileep KV, Mandal PK, Karthe P, Sadasivan C and Haridas M, 2012. AntiInflammatory Property of n-hexadecanoic acid: Structural evidence and kinetic assessment. Chem. Biol. Drug Des. 80: 434-439.

Banni S, Angioni E, Murru E, Carta G, Melis MP, Bauman D, Dong Y and Ip C, 2001. Vaccenic acid feeding increases tissue levels of conjugated linoleic acid and suppresses development of premalignant lesions in rat mammary gland. Nutr. Cancer. 41: 91-97.

Begum HA, Hamayun M, Shad N, Yaseen T and Asad F, 2018. Nutritional analysis of some selected medicinal plants of Khyber Pakhtunkhwa, Pakistan. Pure Appl. Biol. 7: 955.

Bohm BA and Abyazani MRK, 1994. Flavonoid and condensed tannins from the leaves of Vaccinum raticulation and Vaccinum calcyimium. Pacific. Sci. 48: 458.

Burki S, Burki ZG, Jahan N, Muhammad S, Mohani N, Siddiqui FA and Owais F, 2019. GC-MS profiling, FTIR, metal analysis, antibacterial and anticancer potential of Monotheca buxifolia (Falc.) leaves. Pak. J. Pharm. Sci. 2: 32.

D'Archivio M, Filesi C, Varì R, Scazzocchio B and Masella R, 2010. Bioavailability of the polyphenols: status and controversies. Int. J. Mol. Sci. 11:1321-1342.

Dinu M, Whittaker A, Pagliai G, Benedettelli S and Sofi F, 2018. Ancient wheat species and human health: biochemical and clinical implications. J. Nutr. Biochem. 52: 1-9.

EFSA, 2012. EFSA panel on dietetic products, nutrition, and allergies (NDA). 2012. Scientific opinion on dietary reference values for protein. EFSA J. 10: 2557.

Gu CH, Li H, Levons J, Lentz K, Gandhi RB, Raghavan K and Smith RL, 2007. Predicting effect of food on extent of drug absorption based on physicochemical properties. Pharmaceutical research. Pharm. Res. 24: 1118-1130.

Harborne JB, 1998. Phytochemical methods, A Guide to Modern Techniques of Plant Analysis, Chapman and Hall, New York, USA. p. 279.

Hijazi MA, El-Mallah A, Aboul-Ela M and Ellakany A, 2017. Evaluation of analgesic activity of Papaver libanoticum extract in mice: involvement of opioids receptors. Evid.-Based Complementary Altern. Med. Article ID 8935085

Ishimi Y, 2010. Nutrition and bone health. Magnesium and bone. Clin. Calcium. 20: 762-7. PMID: 20445288

Jan S, Khan MR, Rashid U and Bokhari J, 2013. Assessment of antioxidant potential, total phenolics and flavonoids of different solvent fractions of Monotheca buxifolia Fruit. Osong Public Health Res. Perspect. 4: 246-254.

Javed S, Oise IE, Nahar L, Ismail FMD, Mahmood Z and Sarker SD, 2016. Isolation, Identification and Antiproliferative Activity of Triterpenes from the Genus Monotheca A. DC. Rec. Nat. Prod. 10(6): 782-787.

Khan I, Ali JS, Ul-Haq I and Zia M, 2020. Biological and phytochemicals properties of Monotheca buxifolia: An Unexplored Medicinal Plant. Pharm. Chem J. 54: 293-301.

Krishnamoorthy K and Subramaniam P, 2014. Phytochemical profiling of leaf, stem, and tuber parts of Solena amplexicaulis (Lam.) Gandhi using GC-MS. Article ID 567409.

Lee CC and Houghton P, 2005. Cytotoxicity of plants from Malaysia and Thailand used traditionally to treat cancer. J. Ethnopharmacol. 100: 237-243.

Maragreth BC, Miranda G and Sarachine J, 2009. Biological activities of Lupeol. Int. J. Biomed. Pharm. Sci. 3: 46.

Mosmann T, 1983. Rapid colorimetric assay for cellular growth and survival: Application to proliferation and cytotoxicity assays. J. Immunol. Methods. 65: 55.

Mroczek T, Dymek A, Widelski J and Wojtanowski KK, 2020. The bioassay-guided fractionation and identification of potent acetylcholinesterase inhibitors from Narcissus c.v. 'Hawera' using optimized vacuum liquid chromatography, high resolution mass spectrometry and bioautography. Metabolites. 10: 395.

Nagao K and Yanagita T, 2010. Medium-chain fatty acids: functional lipids for the prevention and 
treatment of the metabolic syndrome. Pharmacol. Res. 61: 208-212.

Obadoni BO and Ochuko PO, 2001. Phytochemical studies and comparative efficacy of the crude extract of some homeostatic plants in Edo and Delta states of Nigeria. Global. J. Pure. Appl. Sci. 8: 203.

Raikos V and Ranawana V, 2017. Designing emulsion droplets of foods and beverages to enhance delivery of lipophilic bioactive components-a review of recent advances. Int. J. Food Sci. Technol. 52: 68-80.

Selby-Pham SNB, Miller RB, Howell K, Dunshea F and Bennett LE, 2017. Physicochemical properties of dietary phytochemicals can predict their passive absorption in the human small intestine. Sci. Rep. 7: 1931.

Sofowora A, 1993. Medicinal Plants and Traditional Medicines in Africa, John Wiley and Sons, Inc. p. 150.

Soyano A and Gomez M, 1999. Role of iron in immunity and its relation with infections. Archivos latinoamericanos de nutricion. Arch. Latinoam. Nutr. 49: 40S-46S.

Sree L and Vijayalakshmi K, 2018. Evaluation and mineral analysis in the leaves of an indigenous medicinal plant, Alternanthera Sessilis. Int. J. Health Sci. Res. 8: 244-253.

Ullah I, Khan JA, Adhikari A and Shahid M, 2016. Hepatoprotective effect of Monotheca buxifolia fruit against antitubercular drugs-induced hepatotoxicity in rats. Bangladesh J. Pharmacol. 11: 248-256.
Vlaisavljević S, Jelača S, Zengin G, Mimica-Dukić N, Berežni S, Miljić M and Stevanović ZD, 2019. Alchemilla vulgaris agg. (Lady's mantle) from Central Balkan: antioxidant, anticancer and enzyme inhibition properties. RSC Adv. 9: 37474-83.

Williamson EM, Okpako DT and Evans FJ, 1997. Selection, preparation and pharmacological evaluation of plant material. Phytother. Res. 1: 131.

Zimmerman M, 1983. Ethical guidelines for investigation of experimental pain in conscious animal. Pain. 16: 109-110.

\section{Contribution of Authors}

Javed S: Performed experiments, collected data, analyzed data and wrote first draft of the manuscript

Shoaib A: Helped in data analysis and edited manuscript

Mehmood Z: Designed experiment and helped in $\mathrm{n}$ data collection

Nawaz S: Performed analgesic and cytotoxic activity assays

Khan KM: Contributed in supervising

chromatographic isolation and characterization of compounds 